\title{
Photosynthetic responses of three common mosses from continental Antarctica
}

\author{
STEFAN PANNEWITZ1*, T.G. ALLAN GREEN ${ }^{2}$, KADMIEL MAYSEK $^{3}$, MARK SCHLENSOG ${ }^{1}$, ROD SEPPELT $^{4}$, \\ LEOPOLDO G. SANCHO ${ }^{5}$, ROMAN TÜRK ${ }^{6}$ and BURKHARD SCHROETER ${ }^{1}$. \\ ${ }^{1}$ Botanisches Institut, Christian-Albrechts-Universität Kiel, Olshausenstr. 40, D-24098 Kiel, Germany \\ ${ }^{2}$ Biological Sciences, University of Waikato, Private Bag 3105, Hamilton, New Zealand \\ ${ }^{3}$ Dept. of Environmental Sciences and Energy Research, Weizmann Institute of Science, Rehovot 76100, Israel \\ ${ }^{4}$ Australian Antarctic Programme, Channel Highway, Kingston, TAS 7050, Australia \\ ${ }^{5}$ Dep. Biologia Vegetal II, Fac. De Farmacia, Universidad Complutense, ES-28040 Madrid, Spain \\ ${ }^{6}$ Institut für Pflanzenphysiologie, Paris Lodron University Salzburg, Hellbrunnerstr. 34, A-5020 Salzburg, Austria \\ *corresponding address: Clausthaler Str. 25, 28205 Bremen, Germany \\ Spannewitz@uni-bremen.de
}

\begin{abstract}
Predicting the effects of climate change on Antarctic terrestrial vegetation requires a better knowledge of the ecophysiology of common moss species. In this paper we provide a comprehensive matrix for photosynthesis and major environmental parameters for three dominant Antarctic moss species (Bryum subrotundifolium, B. pseudotriquetrum and Ceratodon purpureus). Using locations in southern Victoria Land, (Granite Harbour, $\left.77^{\circ} \mathrm{S}\right)$ and northern Victoria Land $\left(\right.$ Cape Hallett, $\left.72^{\circ} \mathrm{S}\right)$ we determined the responses of net photosynthesis and dark respiration to thallus water content, thallus temperature, photosynthetic photon flux densities and $\mathrm{CO}_{2}$ concentration over several summer seasons. The studies also included microclimate recordings at all sites where the research was carried out in field laboratories. Plant temperature was influenced predominantly by the water regime at the site with dry mosses being warmer. Optimal temperatures for net photosynthesis were $13.7^{\circ} \mathrm{C}, 12.0^{\circ} \mathrm{C}$ and $6.6^{\circ} \mathrm{C}$ for $B$. subrotundifolium, B. pseudotriquetrum and C. purpureus, respectively and fall within the known range for Antarctic mosses. Maximal net photosynthesis at $10^{\circ} \mathrm{C}$ ranked as B. subrotundifolium $>$ B. pseudotriquetrum $>$ C. purpureus. Net photosynthesis was strongly depressed at subzero temperatures but was substantial at $0^{\circ} \mathrm{C}$. Net photosynthesis of the mosses was not saturated by light at optimal water content and thallus temperature. Response of net photosynthesis to increase in water content was as expected for mosses although B. subrotundifolium showed a large depression $(60 \%)$ at the highest hydrations. Net photosynthesis of both B. subrotundifolium and B. pseudotriquetrum showed a large response to increase in $\mathrm{CO}_{2}$ concentration and this rose with increase in temperature; saturation was not reached for $B$. pseudotriquetrum at $20^{\circ} \mathrm{C}$. There was a high level of variability for species at the same sites in different years and between different locations. This was substantial enough to make prediction of the effects of climate change very difficult at the moment.
\end{abstract}

Received 3 November 2004, accepted 18 April 2005

Key words: bryophytes, global change, light compensation, microclimate, net photosynthesis, Victoria Land

\section{Introduction}

In Antarctica, vascular plants are confined to north-western parts of the Antarctic Peninsula so that the vegetation of the main continent is composed entirely of cryptogams (Smith 1984). Lichens dominate on rock surfaces, or within rocks (endolithic communities) but are also found on the surface of moss turfs. Liverworts are not extensive in continental Antarctica and reach their southern limit at Botany Bay, Granite Harbour, southern Victoria Land $\left(77^{\circ} \mathrm{S}\right)$. In continental Antarctica mosses are common and occur at their greatest biomasses in areas with regular meltwater in summer, in combination with algae and cyanobacteria.

This paper is dedicated to Professor Dr Ludger Kappen, pioneer of Antarctic ecology, on the occasion of his 70th birthday.
There is little doubt that mosses owe their presence in continental Antarctica to their poikilohydric lifestyle which gives them the ability to tolerate the extreme cold of the Antarctic winter (Kappen \& Valledares 1999, Schlensog et al. 2004). Although regular desiccation has also been assumed to be part of this lifestyle it now appears that mosses in wet areas can remain moist and continuously active over long periods (Smith 1999, Schlensog \& Schroeter 2000, Pannewitz et al. 2003a). Wetting and rehydration events seem to be scarce once the mosses have become rewetted in a meltwater site. The preconception that these plants are in a harsh, highly variable habitat may need to be revisited, especially for the productive summer season. It is also becoming clear that there are a variety of environments for mosses in Antarctica ranging from xeric, 
rock cracks and fellfield (feldmark) to mesic, regular meltwater sites (Longton 1988, Kappen et al. 1989, Smith 1999, Schlensog \& Schroeter 2000). The different environments appear to influence the rates at which organisms recover after desiccation (Schlensog et al. 2004) with mosses from continuously wet sites recovering only slowly compared to xeric species.

A habitat in which the plants are continuously hydrated brings other potential stresses. There is the possibility of damage from the high irradiances that can occur for long periods of the day, freeze/thaw events and from increased ultraviolet radiation (UV) in the spring and early summer as a result of atmospheric ozone depletion (Robinson et al. 2003). The mosses, however, appear to be not only well protected against these stresses (Post 1990, Green et al. $2000 \mathrm{~b}$ ) but also to be able to respond rapidly to changes in UV (Newsham et al. 2003, Green et al. 2005) and freeze/thaw events (Lovelock et al. 1995a, 1995b). It is possible that the ability of mosses to adapt themselves to environmental stress has been underestimated.

The performance of Antarctic mosses has been reviewed (Longton 1988, Green et al. 1999, Kappen \& Schroeter 2002) but the existing knowledge it is not extensive. Smith (1999) has reviewed the ecological situation of the three species studied in this paper and notes that all three are widespread in continental Antarctica. There is a growing interest in the use of changes in vegetation composition and performance along latitudinal gradients as a means to demonstrate and detect the effects of expected global climate change (Canadell et al. 2000), especially changes in temperature. However, there is a lack of studies comparing photosynthetic performance, as maximal net photosynthesis (NP) or optimal temperatures for NP (Smith 1999), for specimens of the same moss species either at a single location or at several locations. Further, little is known about year to year variability in NP or the factors that might produce such variability although this information is likely to be vital to the interpretation of any vegetation changes or the estimation of likelihood to change. There is also a lack of knowledge about the response of mosses to environmental factors such as low temperatures, especially at or below water freezing point, and to $\mathrm{CO}_{2}$ concentration. The latter is of special interest because very high levels of $\mathrm{CO}_{2}$ have been reported amongst mosses in Antarctica (Tarnawski et al. 1992, Green et al. 2000a). All of these factors could have major effects on the productivity of the plants.

In this paper we report results for three moss species (Bryum subrotundifolium, B. pseudotriquetrum and Ceratodon purpureus) at two locations (Victoria Land Granite Harbour, $77^{\circ} \mathrm{S}$ and Cape Hallett $72^{\circ} \mathrm{S}$ ). The same species have also been studied at Edmonson Point ( $\left.74^{\circ} 20^{\prime} \mathrm{S}\right)$ by Smith (1999). The results provide an initial insight into differences in NP response of continental Antarctic bryophytes to major environmental variables and to the level of variability in these responses.

\section{Material and methods}

\section{Research sites}

The research was carried out at Cape Hallett, northern Victoria Land $\left(72^{\circ} 19^{\prime} \mathrm{S}, 170^{\circ} 13.5^{\prime} \mathrm{E}\right.$, January/February 1999) and Granite Harbour, southern Victoria Land

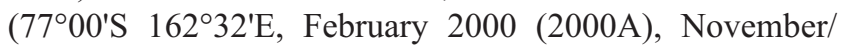
December 2000 (2000B) and January 2001).

Cape Hallett (an Antarctic Specially Protected Area 106, see Lewis Smith et al. 1994) rises steeply from sea level to about $300 \mathrm{~m}$ a.s.l. This scree slope protects the vegetation from strong winds and shades it at night. Cape Hallett is usually snow free during the late spring and summer season, precipitation, exclusively as snow, is low and the mean summer temperature is $-2.4^{\circ} \mathrm{C}$ (Rudolph 1966a). High insolation during the summer season results in thawing of a local glacier, semi-permanent snow patches and the snow field at the top of the scree, so that meltwater flows often and forms numerous small meltwater channels through the vegetated areas. A high nutrient input is guaranteed by the rich bird life in the area (Green et al. 2000a).

Cape Geology and Botany Bay are situated in the ASPA 154 in Granite Harbour, an area with exceptional moss and lichen vegetation (Taylor 1913). During the summer season Cape Geology and Botany Bay are snow free. The area is protected from high winds and several small water flows occur in Botany Bay due to thawing of a snow field on the summit of the adjacent ridge.

\section{Investigated species}

Bryum subrotundifolium Jaeg., is a widely distributed species on banks and disturbed soils in moist or wet sites in continental Antarctica (Seppelt \& Green 1998, Smith 1999). It represents a yellowish-green species close to B. argenteum Hedw., that appears to dominate in Victoria Land (Seppelt et al. 1995, Seppelt \& Green 1998, Ochyra 1998). Samples were collected at Botany Bay as well as at Cape Hallett where B. subrotundifolium completely covers large areas.

The common, bipolar moss B. pseudotriquetrum (Hedw.) C.F. Gaertn., B. Meyer et Scherb., previously referred to in Antarctica as B. algens Card. (Seppelt 1984), grows as a dense turf in moist or wet places along meltwater channels and in low lying flush areas (Ochyra 1998, Smith 1999). Samples were collected from a closed turf area located outside the ASPA 106 in Cape Hallett where the moss grew on a small bench close to the bottom of the scree slope. The species is present at Botany Bay, Granite Harbour and this seems to be its southern limit for extensive growth. It is only a minor component in the McMurdo Dry Valleys.

Ceratodon purpureus (Hedw.) Brid., also known as C. antarcticus Card., is a cosmopolitan moss which is common in the maritime Antarctic and widely distributed on the continent (Ochyra 1998, Smith 1999). It forms dense 
brownish turfs in a variety of habitats. Samples were collected at Botany Bay where it forms extended turfs on rocky terraces and on disturbed soils in areas of consistent water flow which contrasts to the drier sites reported by Smith (1999). It appears not to be present at Cape Hallett although it has been reported close by (Crater Cirque, $72^{\circ} 38^{\prime} \mathrm{S} 169^{\circ} 22^{\prime} \mathrm{E}$ ).

\section{Climatic conditions}

Local climatic conditions were continuously recorded at both sites during the research using data loggers (SQ1021, Grant Instruments, UK). PPFD (photosynthetic photon flux density in the 400-700 nm waveband, $\leq 2000 \mu \mathrm{mol} \mathrm{m}^{-2} \mathrm{~s}^{-1}$ ) was measured with GaAsP photodiodes (Hamasutu, J.) equipped with cosine correction according to Pontaillier (1990). The sensors were calibrated using an optical radiation calibrator (1800-02, LiCor, USA). The photodiodes were mounted on the ground both horizontally and with a similar exposure as the moss. The temperatures of the moss turfs $\left(\mathrm{TT}^{\circ} \mathrm{C}\right)$ were measured with microthermistors (Ø $0.3 \mathrm{~mm}$, Grant, UK) placed in the top layer $(5 \mathrm{~mm})$. Air temperature (thermistors, $\varnothing 0.3 \mathrm{~mm}$, Grant, UK) and relative air humidity (capacitance humidity probes, HMP35, Vaisala, SF) were recorded in a ventilated screen at $1 \mathrm{~m}$ above the ground.

\section{$\mathrm{CO}_{2}$ gas exchange}

NP and dark respiration (DR) of the mosses were measured using compact mini-cuvette systems (CMS4P, Walz GmbH, FRG) operated in the differential mode (see Schroeter et al. 1994). The open flow system was combined with a cooling trap in order to remove water from the gas stream before entering the non-dispersive infrared gas analyser (Binos 100, Rosemount, FRG). When required, light was provided by an incandescent halogen lamp (FL 400, 400F, Walz $\mathrm{GmbH}, \mathrm{FRG})$. The $\mathrm{CO}_{2}$ concentration $\left(c_{\mathrm{a}}\right)$ of the gas stream was normally that of ambient air but, when required, was altered using a $\mathrm{CO}_{2}$ mixer (Walz $\mathrm{GmbH}$, FRG). The measurement systems were installed at the field camps in Cape Hallett and Granite Harbour. Photosynthetic response to ambient climatic conditions were performed using the same system but with the CMS4P in tracking mode.

The moss was collected in pieces of $c .8 \mathrm{~cm}^{2}$ and immediately transported to the field laboratory. Debris and dead moss material was removed and the sample trimmed to a thickness of about $8 \mathrm{~mm} . \mathrm{CO}_{2}$ gas exchange measurements took place immediately after collection. NP and DR rates were expressed on an area base and gross photosynthetic rate (GP) calculated as (NP+ DR).

The dependence of NP and DR on water content (WC) was measured for both B. subrotundifolium and B. pseudotriquetrum collected fresh from the field. The prepared moss samples were sprayed and then submerged in water.
Adherent water was shaken off and the maximally hydrated sample weighed on a precision balance (Bp310S, Sartorius, FRG, accuracy: $1 \mathrm{mg}$ ) before it was enclosed in the minicuvette. Samples were removed every $30 \mathrm{~min}$ and reweighed for later determination of WC (d.wt., $24 \mathrm{~h}$ $105^{\circ} \mathrm{C}$ ). Between weighings, net $\mathrm{CO}_{2}$ exchange was first recorded at $500 \mu \mathrm{mol} \mathrm{m}^{-2} \mathrm{~s}^{-1}(\mathrm{NP})$ and then at $0 \mu \mathrm{mol} \mathrm{m}^{-2} \mathrm{~s}^{-1}$ PPFD (DR) with TT always maintained at $10^{\circ} \mathrm{C}$.

Photosynthetic response to PPFD and TT was determined for each sample by measuring NP from 0 to about $1300 \mu \mathrm{mol} \mathrm{m} \mathrm{m}^{-2} \mathrm{~s}^{-1}$ at $5 \mathrm{~K}$ intervals from -5 to $+30^{\circ} \mathrm{C}$. Ambient air was used with $c_{\mathrm{a}}$ of $350-370 \mathrm{ppm}$. WC of the samples was regularly checked by weighing the sample and adjusted to, or close to, optimal levels because a certain amount of evaporative water loss could not be avoided.

The photosynthetic responses of $B$. subrotundifolium and B. pseudotriquetrum to $c_{\mathrm{a}}(100,200,360,620,800,1000$, $1500,2000 \mathrm{ppm}$ ) were determined only at Cape Hallett. NP were first measured at near ambient $c_{\mathrm{a}}(360 \mathrm{ppm})$ at PPFD between 0 and $1350 \mu \mathrm{mol} \mathrm{m} \mathrm{m}^{-2} \mathrm{~s}^{-1}$ and at 0,10 and $20^{\circ} \mathrm{C} \mathrm{TT}$. Measurements were repeated stepwise to $2000 \mathrm{ppm} \mathrm{CO}_{2}$, the measurement at near ambient was then repeated and, finally, $c_{\mathrm{a}}$ reduced stepwise to $100 \mathrm{ppm}$. A repetition of the individual experiments with a statistically relevant number of samples was impossible due to logistic restrictions. Diel measurements were also made at Granite Harbour with specimens at ambient or elevated (about $2000 \mathrm{ppm}$ ) $\mathrm{CO}_{2}$.

\section{Results}

\section{Climatic conditions}

The maxima and minima for PPFD incident on the mosses are summarized in Table I and daily PPFD for both moss species at Granite Harbour are given in Fig. 1. Zero PPFD was never measured at Granite Harbour but, because of the lower latitude, did occur towards the end of the research period at Cape Hallett. However, at both locations, the sun vanished behind mountains for part of each night resulting

Table I. Minima and maxima for PPFD $\left(\mu \mathrm{mol} \mathrm{m} \mathrm{m}^{-2} \mathrm{~s}^{-1}\right)$ and moss turf temperatures $\left(\mathrm{TT}^{\circ} \mathrm{C}\right.$ ) measured at two continental Antarctic sites (Cape Hallett, CH; Granite Harbor, GH) during the summer seasons 1999, 2000 and 2001.

\begin{tabular}{|c|c|c|c|c|c|c|}
\hline \multirow[t]{2}{*}{ Site } & \multirow[t]{2}{*}{ Date } & \multirow[t]{2}{*}{ Species } & \multicolumn{2}{|c|}{$\mathrm{TT}\left({ }^{\circ} \mathrm{C}\right)$} & \multicolumn{2}{|c|}{ 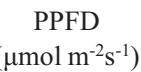 } \\
\hline & & & $\mathrm{T}_{\max }$ & $\mathrm{T}_{\min }$ & $\max$ & $\min$. \\
\hline \multirow[t]{2}{*}{$\mathrm{CH}$} & \multirow{2}{*}{ 4.01.-15.02.1999 } & B. subrotu & 21.2 & -5.9 & \multirow[t]{2}{*}{1982} & \multirow[t]{2}{*}{0} \\
\hline & & B.ps & 24.5 & -2.0 & & \\
\hline \multirow[t]{4}{*}{$\mathrm{GH}$} & \multirow[t]{2}{*}{$14.01 .-30.01 .2000$} & B. subrotundifolium & 23.5 & -8.2 & \multirow[t]{3}{*}{1979} & \multirow[t]{3}{*}{19} \\
\hline & & C. purpureus & 18.6 & -1.8 & & \\
\hline & \multirow[t]{2}{*}{ 23.11.-11.12.2000 } & B. subrotundifolium & & & & \\
\hline & & pot. active* & 17.4 & -9.3 & 1639 & 69 \\
\hline \multicolumn{2}{|c|}{$12.12 .2000-16.01 .2001$} & pot. inactive* & 38.2 & -12.2 & 2000 & 73 \\
\hline \multicolumn{2}{|c|}{$23.11 .2000-24.01 .2001$} & C. purpureus & 35.7 & -10.3 & 2000 & 40 \\
\hline
\end{tabular}

*potentially active and inactive time of $B$. subrotundifolium during the summer season 2000/2001 (for further explanation see text). 
in a rapid decrease in solar radiation and surface soil and water freezing almost every day (see also Rudolph 1966a). Daily maxima were often very high at both locations and, at Granite Harbour, 9\% of the readings were above $1500 \mu \mathrm{mol}$ $\mathrm{m}^{-2} \mathrm{~s}^{-1}$ and values over $2000 \mu \mathrm{mol} \mathrm{m} \mathrm{m}^{-2} \mathrm{~s}^{-1}$ were measured on about two thirds of the days (horizontal sensor, Fig. 1a)

There were no days with air temperature continuously above freezing but the high incident radiation meant that TT exceeded air temperature for most of the time at both locations. At Cape Hallett, the moss turf temperature was above $0^{\circ} \mathrm{C}$ for $55 \%$ of the readings in contrast to air temperature which was below $0^{\circ} \mathrm{C}$ for $88 \%$ of the readings. Absolute thallus temperature maxima were $21.2^{\circ} \mathrm{C}$ and $24.5^{\circ} \mathrm{C}$, and minima were $-5.9^{\circ} \mathrm{C}$ and $-2.0^{\circ} \mathrm{C}$, for $B$. subrotundifolium and $B$. pseudotriquetrum, respectively. TT of B. subrotundifolium between $-2^{\circ} \mathrm{C}$ and $0^{\circ} \mathrm{C}$ were most fequent with $34 \%$ (of $2 \mathrm{k}$ bands), but $55 \%$ of the readings were $>0^{\circ} \mathrm{C}$, with $47 \%$ between $1^{\circ} \mathrm{C}$ and $11^{\circ} \mathrm{C}$.

Greater extremes in TT were measured at Granite Harbour with C. purpureus reaching $35.7^{\circ} \mathrm{C}$ (20 December) and a minimum of $-12.2^{\circ} \mathrm{C} \quad(15$ January $)$. TT of C. purpureus between $-2^{\circ} \mathrm{C}$ and $2^{\circ} \mathrm{C}$ were most frequent with $30 \%$ of the readings $\leq 0^{\circ} \mathrm{C}$ and above $0^{\circ} \mathrm{C}$ and $12^{\circ} \mathrm{C}$ for
$63 \%$ and $27 \%$ of the time, respectively (Fig. 1e). The most common TT for B. subrotundifolium were between $-2^{\circ} \mathrm{C}$ and $2{ }^{\circ} \mathrm{C}(36 \%)$ and the moss turf was above $0^{\circ} \mathrm{C}$ for $66 \%$ of the time with a maximum of $38.2^{\circ} \mathrm{C}$ (Fig. 1c). Daily maxima and minima were much less extreme when the plants were wet and the most frequent TT for moist thalli were still between $-2^{\circ} \mathrm{C}$ and $2{ }^{\circ} \mathrm{C}(58 \%)$, with $49 \%$ of the readings $\leq 0^{\circ} \mathrm{C}$ and another $49 \%$ between $1^{\circ} \mathrm{C}$ and $15^{\circ} \mathrm{C}$. TT of $C$. purpureus were also affected by hydration status and, when wet, hardly declined below $0^{\circ} \mathrm{C}$ during the first nights of measurements (23 November-5 December 2000). This probably indicated a buffering effect from the high WC in the moss. Mosses were hydrated for long periods with intermediate dry phases. Chl $a$ fluorescence measurements (data not show, for further details on methods see Pannewitz et al. 2003a) showed that B. subrotundifolium was potentially active, i.e. wet, from 23 November-11 December 2000, and after 15 January 2001.

\section{$\mathrm{CO}_{2}$ gas exchange}

Diel $\mathrm{CO}_{2}$ gas exchange

A comparison of the photosynthetic responses of

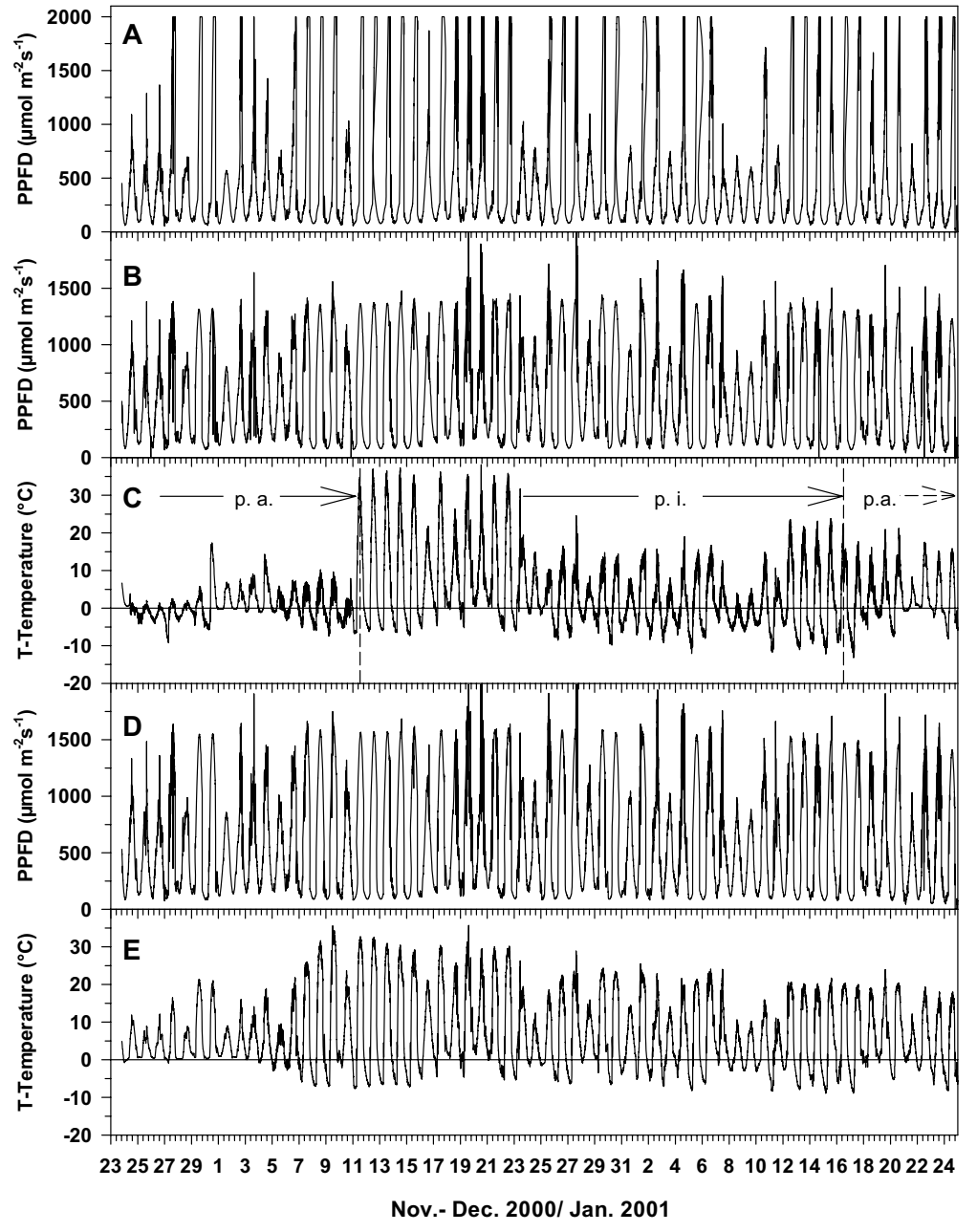

Fig. 1. a. Daily course of ambient PPFD (horizontal) and at moss turf level of b. B. subrotundifolium and d. C. purpureus), as well as the corresponding turf temperatures (C+E) measured between 23 November 2000 and 24 January 2001 at Granite Harbour. c. indicates the potentially active (p.a.) and inactive (p.i.) time of B. subrotundifolium. 


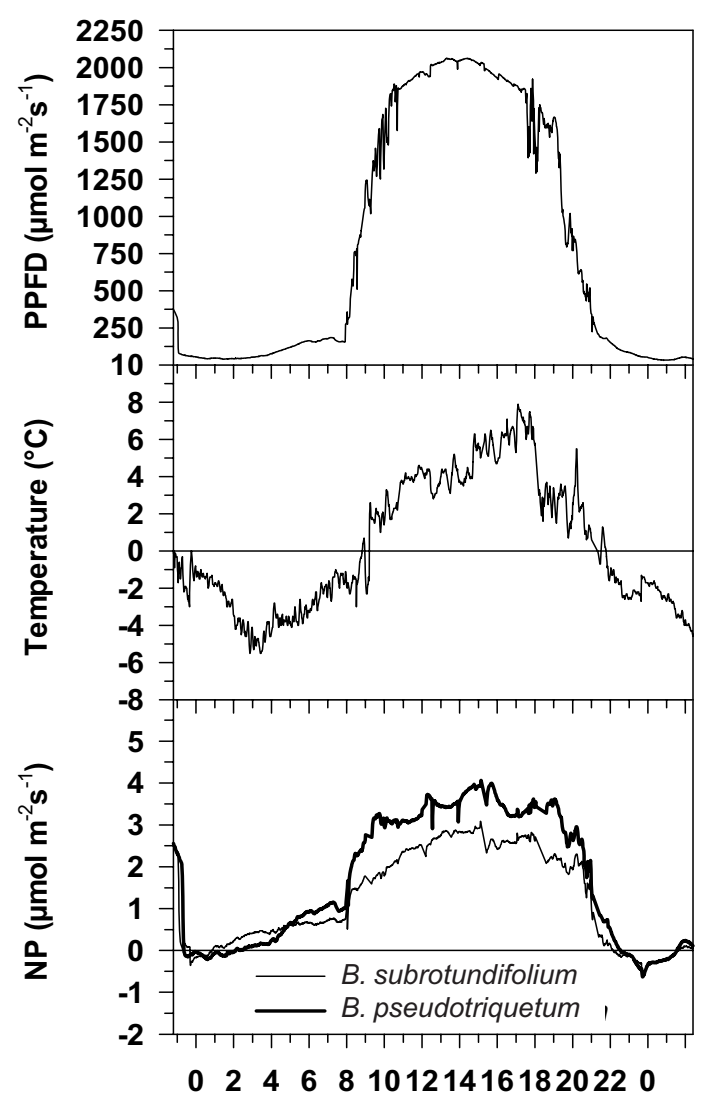

20 Jan. 1999

Fig. 2. Diurnal course of net photosynthesis (NP) of Bryum subrotundifolium and B. pseudotriquetrum under similar ambient climatic conditions measured on 20 January 1999 at Cape Hallett $\left(72^{\circ} 19^{\prime} \mathrm{S}\right)$. Thallus temperature $\left({ }^{\circ} \mathrm{C}\right)$ is shown for B. subrotundifolium.

B. subrotundifolium and B. pseudotriquetrum to ambient conditions on 20 January 1999 at Cape Hallett is presented in Fig. 2. The typical diel pattern for PPFD was a sharp rise at about $08 \mathrm{~h} 00$ and a sudden decline around $20 \mathrm{~h} 00$, both due to the shadowing effect from the cliffs to the east of the research site. TT tracked PPFD and showed a sharp increase and decrease at the same times. Respiration occurred when PPFD reached its nightly minimum of around $30 \mu \mathrm{mol} \mathrm{m} \mathrm{m}^{-2}$ $\mathrm{s}^{-1}$ and TT fell below $0^{\circ} \mathrm{C}$. However, the respiration rates at TT of $-3^{\circ} \mathrm{C}$ were very low $\left(\leq 0.2 \mu \mathrm{mol} \mathrm{m}^{-2} \mathrm{~s}^{-1}\right)$ and a slight increase in PPFD to $>50 \mu \mathrm{mol} \mathrm{m}^{-2} \mathrm{~s}^{-1}$ resulted in positive NP in both species although TT were still below zero. At about 15:00 $\mathrm{h}$ the samples were exposed to maximal measured PPFD of around $2000 \mu \mathrm{mol} \mathrm{m} \mathrm{m}^{-2} \mathrm{~s}^{-1}$, TT was $6^{\circ} \mathrm{C}$ and maximal NP rates were $4 \mu \mathrm{mol} \quad \mathrm{CO}_{2} \mathrm{~m}^{-2} \mathrm{~s}^{-1}$ for B. pseudotriquetrum and $3 \mu \mathrm{mol} \quad \mathrm{CO}_{2} \mathrm{~m}^{-2} \mathrm{~s}^{-1}$ for B. subrotundifolium. Bryum subrotundifolium had $27 \%$ lower daily $\mathrm{CO}_{2}$ gain per day than B. pseudotriquetrum $\left(24.7 \mu \mathrm{mol} \mathrm{CO} \mathrm{CO}_{2} \mathrm{~m}^{-2} \mathrm{~d}^{-1}\right)$ under very similar microclimatic conditions.

Diel $\mathrm{CO}_{2}$ gas exchange measurements were also

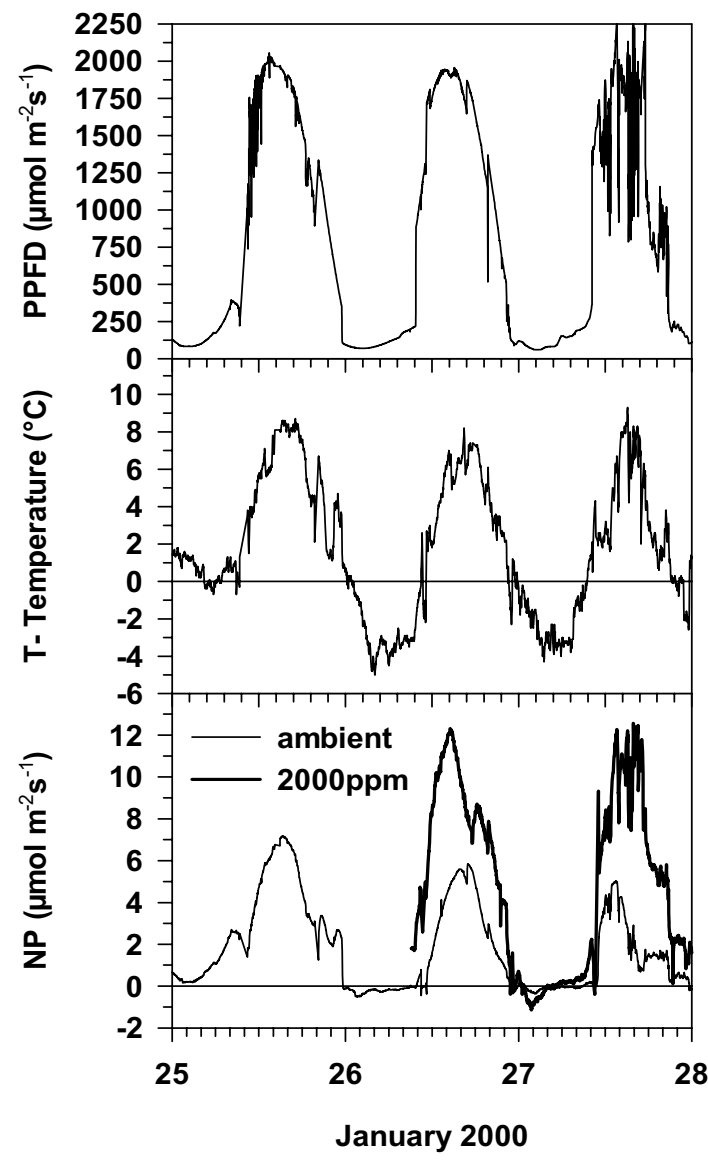

Fig. 3. Diurnal course of net photosynthesis (NP) of Bryum subrotundifolium, at the ambient $\mathrm{CO}_{2}$ concentration, and at elevated $\mathrm{CO}_{2}$ concentration (2000 ppm) under similar ambient climatic conditions in Granite Harbour $\left(77^{\circ} 00^{\prime} \mathrm{S}\right)$. Thallus temperature is shown for $B$. subrotundifolium under ambient $\mathrm{CO}_{2}$ concentration.

performed for B. subrotundifolium at Granite Harbour (25-27 January 2000; Fig. 3). Ambient $c_{\mathrm{a}}$ was raised to $2000 \mathrm{ppm}$ for two days for one sample whilst a second remained at ambient. Carbon gain per day at the higher $\mathrm{CO}_{2}$ level was increased by $63 \%$ on 26 January and by $82 \%$ on 27 January, compared to that at ambient $c_{\mathrm{a}}$. In general TT followed the diel course of PPFD, with minima of $-5^{\circ} \mathrm{C}$ at the lowest PPFD of $48 \mu \mathrm{mol} \mathrm{m} \mathrm{m}^{-2} \mathrm{~s}^{-1}$ and maxima around $10^{\circ} \mathrm{C}$ with PPFD above $2000 \mu \mathrm{mol} \mathrm{m} \mathrm{m}^{-2} \mathrm{~s}^{-1}$. Respiration occurred at low TT and PPFD but was not high with maxima of $0.7 \mu \mathrm{mol} \mathrm{CO} \mathrm{Cm}^{-2} \mathrm{~s}^{-1}$.

Dependence of NP and DR on WC

The dependency of $\mathrm{CO}_{2}$ assimilation rate on moss turf moisture content at Cape Hallett showed the expected pattern for mosses (Fig. 4). At low WC photosynthesis and DR were biochemically limited due to high water deficit in the moss turfs. Increase in hydration was accompanied by a steep rise in both NP and DR. Optimal NP was reached at $390-470 \%$ d.wt. for B. subrotundifolium and $245-330 \%$ 
Table II. Temperature optima for net photosynthesis of Bryum subrotundifolium, B. pseudotriquetrum and Ceratodon purpureus at PPFD ranging between $100 \mu \mathrm{mol} \mathrm{m}^{-2} \mathrm{~s}^{-1}$ and $\mathrm{PPFD}_{\max }{ }^{*}$ measured at two continental Antarctic sites $(\mathrm{CH}=$ Cape Hallett, $\mathrm{GH}=$ Granite Harbor $)$ during the summer seasons 1999, 2000 and 2001.

\begin{tabular}{|c|c|c|c|c|c|c|}
\hline \multirow{3}{*}{$\begin{array}{l}\text { PPFD } \\
\left(\mu \mathrm{mol} \mathrm{m}{ }^{-2} \mathrm{~s}\right.\end{array}$} & \multicolumn{6}{|c|}{ Temperature optimum $\left({ }^{\circ} \mathrm{C}\right)$} \\
\hline & $\left.{ }^{-2} \mathrm{~s}^{-1}\right)$ B. su & brotundif & lium $B$. & udotriquet & C. puı & pureus \\
\hline & $\begin{array}{c}\text { CH } 1999 \\
(n=4)\end{array}$ & $\begin{array}{c}\text { GH } 2000 \\
(n=3)\end{array}$ & $\begin{array}{l}\mathrm{GH} 2001 \\
(n=4)\end{array}$ & $\begin{array}{c}\text { CH } 1999 \\
(n=3)\end{array}$ & $\begin{array}{c}\text { GH } 2000 \\
(n=5)\end{array}$ & $\begin{array}{c}\mathrm{GH} 2001 \\
(n=3)\end{array}$ \\
\hline 100 & 0.9 & 2.7 & 1.1 & -0.2 & 0.8 & 0.3 \\
\hline 200 & 3.4 & 4.9 & 5.0 & 2.9 & 3.4 & 2.0 \\
\hline 500 & 8.2 & 6.8 & 8.8 & 6.7 & 5.2 & 3.3 \\
\hline Max* & 14.9 & 9.1 & 15.9 & 12.0 & 6.8 & 6.3 \\
\hline
\end{tabular}

${ }^{*} \mathrm{PPFD}_{\max }=$ ranging between 1300 and $1350 \mu \mathrm{mol} \mathrm{m}{ }^{-2} \mathrm{~s}^{-1}$

d.wt. for B. pseudotriquetrum. Further increase in hydration resulted in a decline in NP, which was less pronounced in $B$. pseudotriquetrum than in B. subrotundifolium. At full saturation, NP of B. subrotundifolium was about $60 \%$ and of B. pseudotriquetrum about $10 \%$ below the rates at optimal WC. DR showed a similar pattern in B. pseudotriquetrum, with maximal rates occurring at WC between $400-450 \%$ d.wt., but, for B. subrotundifolium, were more or less stable above $250 \%$ d.wt. Maximal NP were similar in both species but DR of $B$. subrotundifolium were about half those of B. pseudotriquetrum.

\section{Response of NP to PPFD and TT}

Net photosynthesis of the three species showed the typical response to increase in PPFD with an initial steep rise and an approach to saturation at the maximal PPFD measured (Fig. 5). NP for all three species were not saturated at optimal or near-optimal TT and maximal PPFD, and none showed any examples of depression in NP due to excessive PPFD. NP response curves for different samples of each species were often very different as indicated by the error bars (Fig. 5). This was especially obvious for C. purpureus (2001) at PPFD $\geq 250 \mu \mathrm{mol} \mathrm{m} \mathrm{m}^{-2} \mathrm{~s}^{-1}(P=0.009)$ with a standard deviation of $2.95 \mu \mathrm{mol} \mathrm{CO} \mathrm{m}^{-2} \mathrm{~s}^{-1}$ at maximal PPFD.

The quantum efficiency $(\Phi$, initial slope of the PPFD response curves) of photosynthesis was temperature
Table III. Light compensation points $\left(\mu \mathrm{mol} \mathrm{m} \mathrm{m}^{-2} \mathrm{~s}^{-1}\right)$ of B. subrotundifolium, B. pseudotriquetrum and Ceratodon purpureus at moss turf temperature (TT) ranging between 0 and $30^{\circ} \mathrm{C}$, measured at two continental Antarctic sites $(\mathrm{CH}=$ Cape Hallett, $\mathrm{GH}=$ Granite Harbor $)$ during the summer seasons 1999, 2000 and 2001. Results are given as the means ( \pm SD) of $n$ independent measurements.

\section{TT $\left({ }^{\circ} \mathrm{C}\right) \quad$ Light compensation $\left(\mu \mathrm{mol} \mathrm{m} \mathrm{m}^{-2} \mathrm{~s}^{-1}\right)$} B. subrotundifolium B.pseudotriquetrum C.purpureus CH 1999 GH 2000 GH $2001 \quad$ CH $1999 \quad$ GH 2000 GH 2001

\begin{tabular}{lrlllrc} 
& $(n=4)$ & $(n=3)$ & $(n=4)$ & $(n=3)$ & $(n=5)$ & $(n=3)$ \\
\hline 0 & $46(28)$ & 12 & $49(17)$ & $42(6)$ & $32(10)$ & $41(5)$ \\
5 & $76(58)$ & $44(2)$ & $66(26)$ & $37(2)$ & $69(13)$ & $93(18)$ \\
10 & $225(74)$ & $92(16)$ & $129(53)$ & $134(34)$ & $129(68)$ & $228(79)$ \\
15 & $213(81)$ & $135(12)$ & $235(71)$ & $260(5)$ & $374(162)$ & $379(131)$ \\
20 & $312(93)$ & $204(5)$ & $329(99)$ & $429(36)$ & & $637 * *$ \\
25 & $392(102)$ & $337(47)$ & $480(172)$ & $840 *$ & & \\
30 & $483 * *$ \\
$* n=2 * * n=1$. & & & & \\
$*$
\end{tabular}
$* n=2, * * n=1$.

independent (ANOVA $P>0.1$ ) and varied between 0.05 and 0.03 in the three species. This contrasts with Smith (1999) who found $\Phi$ to be different for the three species with C. purpureus apparently having the highest efficiency.

Thallus temperature for maximal NP $\left(\mathrm{TT}_{\text {opt }}\right)$ also changed with incident PPFD, so that the lower the light level the lower the $\mathrm{TT}_{\mathrm{opt}}$. Optimal temperatures could even be at subzero temperatures under low PPFD conditions. $\mathrm{TT}_{\text {opt }}$ at maximal PPFD differed between years and location for B. subrotundifolium with a mean $\mathrm{TT}_{\mathrm{opt}}$ of $13.7^{\circ} \mathrm{C}(n=11)$. $\mathrm{TT}_{\text {opt }}$ was $12.0^{\circ} \mathrm{C}$ for B. pseudotriquetrum $(n=3)$ and $6.6^{\circ} \mathrm{C}$ for $C$. purpureus $(n=8)$. The latter species showed little difference in $\mathrm{TT}_{\text {opt }}$ between years (Table II) despite large changes in $\mathrm{NP}_{\max }$.

Assimilation rates at $-5^{\circ} \mathrm{C}$ TT were low in all three mosses (maximal $0.1-0.8 \mu \mathrm{mol} \mathrm{CO}_{2} \mathrm{~m}^{-2} \mathrm{~s}^{-1}$ ) but were always substantial at $0^{\circ} \mathrm{C}$ TT. At $\mathrm{PPFD}_{\max }$ and $0^{\circ} \mathrm{C} \mathrm{TT}$, B. subrotundifolium (1999) had a mean NP of $4.3 \mu \mathrm{mol} \mathrm{CO}$ $\mathrm{m}^{-2} \mathrm{~s}^{-1}(\mathrm{SE}$ mean $=1.1), B$. pseudotriquetrum of $2.6 \mu \mathrm{mol}$ $\mathrm{CO}_{2} \mathrm{~m}^{-2} \mathrm{~s}^{-1}(\mathrm{SE}$ mean $=0.8)$ and C. purpureus $(2001)$ of $1.95 \mu \mathrm{mol} \mathrm{CO} \mathrm{m}^{-2} \mathrm{~s}^{-1}(\mathrm{SE}$ mean $=0.4)$.

DR rose exponentially with increasing TT in all samples $\left(r^{2}=0.93-0.96\right)$. The mean DR for B. pseudotriquetrum
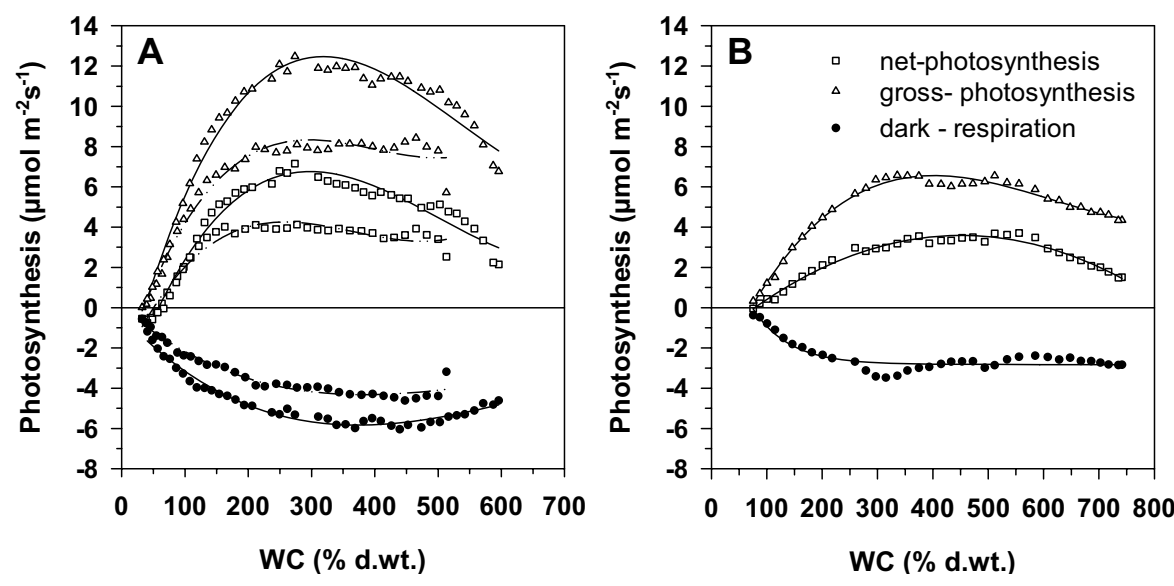

Fig. 4. Gross-photosynthesis (calculated as $\mathrm{GP}=\mathrm{NP}+\mathrm{DR}$ ), net photosynthesis (NP) and dark respiration (DR) for a. Bryum pseudotriquetrum and b. $B$. subrotundifolium related to the moss turf water content (WC, \% d.wt.) measured at $10^{\circ} \mathrm{C}$ turf temperature (TT) and 500/0 $\mu \mathrm{mol} \mathrm{m} \mathrm{m}^{-2} \mathrm{~s}^{-1}$ PPFD in the field laboratory in Cape Hallett ( $\left.72^{\circ} 19^{\prime} \mathrm{S}\right)$. 


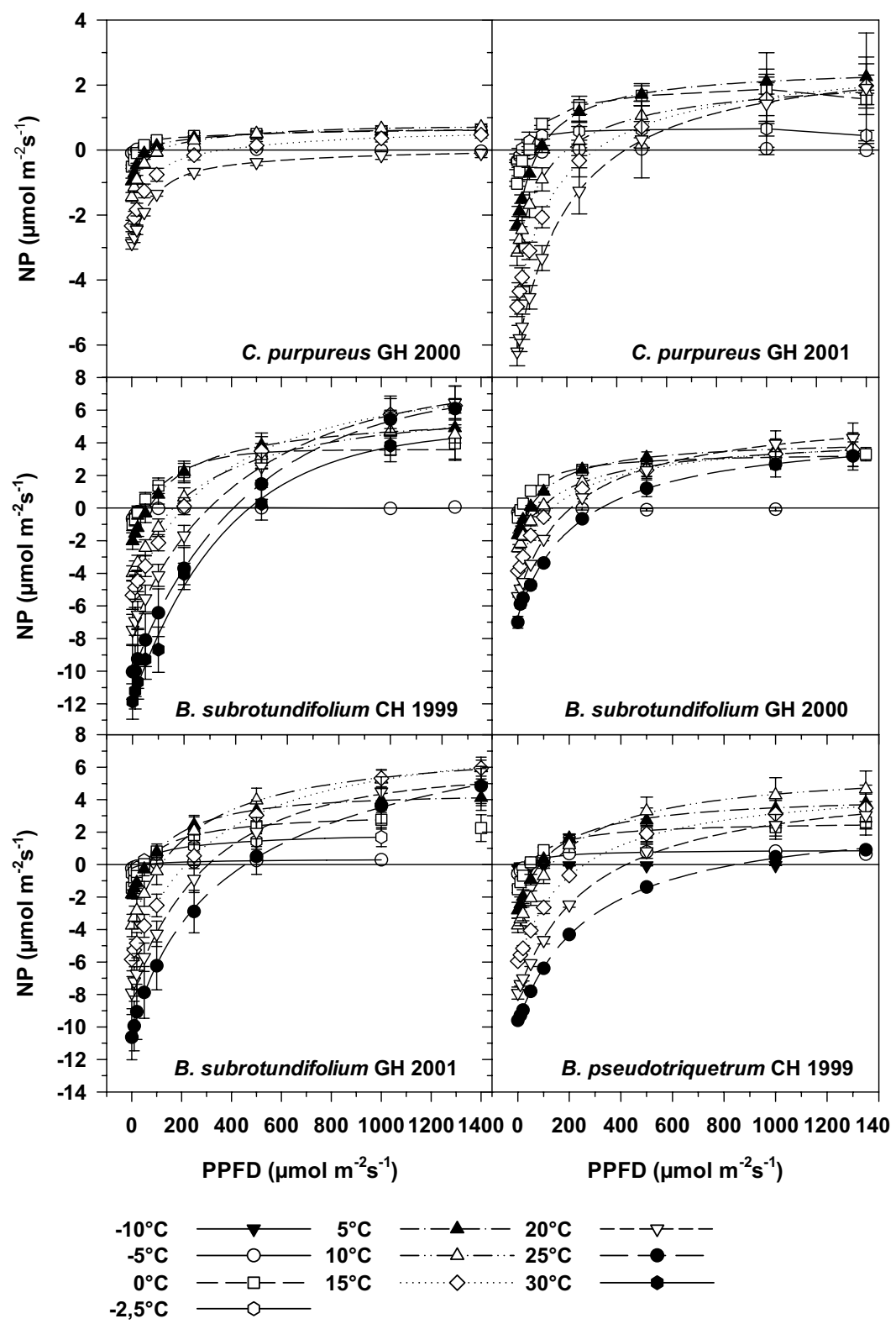

Fig. 5. Dependence of net photosynthesis of C. purpureus, B. subrotundifolium and B. pseudotriquetrum on PPFD $\left(\mu \mathrm{mol} \mathrm{m} \mathrm{m}^{-2} \mathrm{~s}^{-1}\right)$ measured at various temperatures. Data points were obtained from gas exchange measurements in the field laboratory at Cape Hallett $(\mathrm{CH})$ and Granite Harbour (GH). $(n=3)$ was $0.4 \mu \mathrm{mol} \mathrm{CO} \mathrm{m}^{-2} \mathrm{~s}^{-1}$ at $-5^{\circ} \mathrm{C}$ TT and $7.4 \mu \mathrm{mol}$ $\mathrm{CO}_{2} \mathrm{~m}^{-2} \mathrm{~s}^{-1}$ at $20^{\circ} \mathrm{C}$ TT. The corresponding rates for B. subrotundifolium $(n=4)$ were 0.7 and $7.5 \mu \mathrm{mol} \mathrm{CO} \mathrm{m}^{-2}$ $\mathrm{s}^{-1}$ and $12 \mu \mathrm{mol} \mathrm{CO}_{2} \mathrm{~m}^{-2} \mathrm{~s}^{-1}$ at $30^{\circ} \mathrm{C} \mathrm{TT}$. DR rates were variable between years with $B$. subrotundifolium significantly lower at $\mathrm{TT} \geq 15^{\circ} \mathrm{C}$ in samples from the year $2000(P<0.05)$. Ceratodon purpureus had average DR rates of $0.1 \mu \mathrm{mol} \mathrm{CO} \mathrm{m}^{-2} \mathrm{~s}^{-1}$ at $-5^{\circ} \mathrm{C} \mathrm{TT}$ and $2.9 \mu \mathrm{mol} \mathrm{CO}_{2}$ $\mathrm{m}^{-2} \mathrm{~s}^{-1}$ at $20^{\circ} \mathrm{C}$ TT in $2000(n=5)$ compared to $0.34 \mu \mathrm{mol}$ $\mathrm{CO}_{2} \mathrm{~m}^{-2} \mathrm{~s}^{-1}$ and $6.2 \mu \mathrm{mol} \mathrm{CO} \mathrm{m}^{-2} \mathrm{~s}^{-1}(n=3)$, respectively in 2001.

Light compensation $\left(\mathrm{L}_{\mathrm{c}}\right)$ values were affected by changes in DR (Fig. 5). For B. subrotundifolium this meant that NP became positive at $12-46 \mu \mathrm{mol} \mathrm{m} \mathrm{m}^{-2} \mathrm{~s}^{-1}$ PPFD at $0^{\circ} \mathrm{C}$ but required $337-480 \mu \mathrm{mol} \mathrm{m}^{-2} \mathrm{~s}^{-1}$ at $25^{\circ} \mathrm{C}$ TT (Table III) whilst PPFD had to be almost twice as high for
B. pseudotriquetrum $\left(840 \mu \mathrm{mol} \mathrm{m} \mathrm{m}^{-2} \mathrm{~s}^{-1} ; n=2\right)$. Interspecific differences in $\mathrm{L}_{\mathrm{c}}$, were remarkably at $\mathrm{TT}>15^{\circ} \mathrm{C}$, and C. purpureus needed higher PPFD to compensate for respiration than the other two species (Table II).

Response of $\mathrm{CO}_{2}$ exchange to $\mathrm{CO}_{2}$ concentration

The responses of gross photosynthesis (GP) of $B$. subrotundifolium and $B$. pseudotriquetrum to $c_{\mathrm{a}}$ (100-2000 ppm), TT $\left(0,10,20^{\circ} \mathrm{C}\right)$ and incident PPFD are shown in Fig. 6a-f. The dominating effect of TT was obvious for both species with GP depressed at $<10^{\circ} \mathrm{C}$ and at $0^{\circ} \mathrm{C}$ were only around $15 \%$ of those at $20^{\circ} \mathrm{C}$.

NP for both species saturated at around $400 \mu \mathrm{mol} \mathrm{m} \mathrm{m}^{-2} \mathrm{~s}^{-1}$ PPFD at $0^{\circ} \mathrm{C}$ TT but showed no saturation at $10^{\circ} \mathrm{C} \mathrm{TT}$ and, even more clearly, at $20^{\circ} \mathrm{C}$ TT. The response of NP to $c_{\mathrm{a}}$ differed for the two species. Comparisons are made for the 

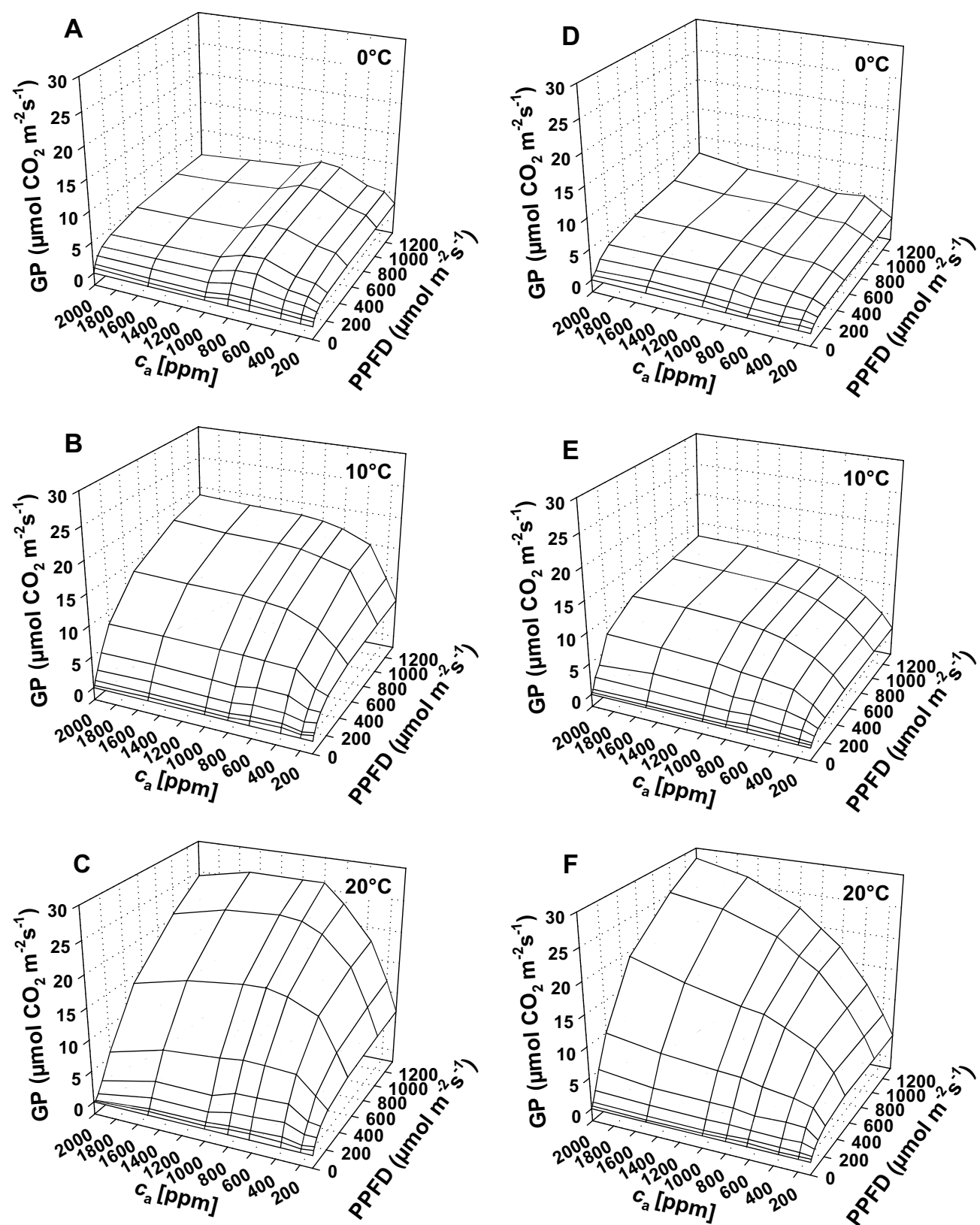

Fig. 6a-c. 3D-mesh plots of gross photosynthesis of B. subrotundifolium measured at turf temperatures between a. $0^{\circ} \mathrm{C}$, b. $10^{\circ} \mathrm{C}$ and c. $20^{\circ} \mathrm{C}$, PPFD between 0 and 1350 $\mu \mathrm{mol} \mathrm{m} \mathrm{m}^{-2}$, and $c_{\mathrm{a}}$ between $100-2000 \mu \mathrm{mol} \mathrm{CO}_{2} \mathrm{~m}^{-2} \mathrm{~s}^{-1}$ in the field laboratory in Cape Hallett. d-f. 3D-mesh plots of gross-photosynthesis of B. pseudotriquetrum measured at turf temperature between d. $0^{\circ} \mathrm{C}$, e. $10^{\circ} \mathrm{C}$ and f. $20^{\circ} \mathrm{C}$, PPFD between 0 and $1350 \mu \mathrm{mol} \mathrm{m}^{-2} \mathrm{~s}^{-1}$, and $c_{\mathrm{a}}$ between 100-2000 $\mu \mathrm{mol} \mathrm{CO}$ $\mathrm{m}^{-2} \mathrm{~s}^{-1}$ in the field laboratory in Cape Hallett. higher PPFD because, as expected, saturation was at lower $c_{\text {a }}$ when response curves were generated at lower PPFD. At $0^{\circ} \mathrm{C}$ and high PPFD both species became $\mathrm{CO}_{2}$ saturated at $c_{\mathrm{a}}$ of 400-600 ppm. Bryum subrotundifolium continued to show $\mathrm{CO}_{2}$ saturation of $\mathrm{NP}$ at about $800 \mathrm{ppm} \mathrm{CO}_{2}$ at $10^{\circ} \mathrm{C}$ and $20^{\circ} \mathrm{C}$. In contrast, $c_{\mathrm{a}}$ required for saturation of NP in B. pseudotriquetrum increased to about $1200 \mathrm{ppm}$ at $10^{\circ} \mathrm{C}$ and was not reached at all at $20^{\circ} \mathrm{C}$.

The responses of NP to $c_{\mathrm{a}}$ are summarized in Table IV where the increase or decrease relative to the nominal ambient $\mathrm{CO}_{2}$ level $(360 \mathrm{ppm})$ have also been calculated. The maximal capacity of photosynthesis at $10^{\circ} \mathrm{C} \mathrm{TT}$ and the highest PPFD used $\left(1350 \mu \mathrm{mol} \mathrm{m} \mathrm{m}^{-2} \mathrm{~s}^{-1}\right)$ was reduced by $79 \%$, for B. subrotundifolium at an ambient $c_{\mathrm{a}}$ of $100 \mathrm{ppm}$ but increased by $48 \%$ at a $c_{\mathrm{a}}$ of $2000 \mathrm{ppm}$. The $c_{\mathrm{a}}$ dependency was even more pronounced in B. pseudo-triquetrum and NP increased by $123 \%$ at $10^{\circ} \mathrm{C} \mathrm{TT,} \mathrm{PPFD}_{\max }$ and a $c_{\mathrm{a}}$ of $2000 \mathrm{ppm}$.

The carboxylation efficiency ( $\alpha$ slope of $\mathrm{CO}_{2}$ response at low $\mathrm{CO}_{2}$ concentration) was PPFD and, to a lesser extent, TT dependent (Table V) and, although not statistically significant appeared to be higher for $B$. subrotundifolium. In both species the $\mathrm{CO}_{2}$ compensation point $(\Gamma)$ decreased with an increasing PPFD but increased at higher thallus temperatures because of the higher rates of respiration (Table V). At any combination of temperature and PPFD $B$. pseudotriquetrum always had a higher $\Gamma$. In general, $\Gamma$ was well below the natural ambient $c_{\mathrm{a}}(360 \mathrm{ppm})$ at all $\mathrm{TT}$ in both tested species except for $B$. pseudotriquetrum at 200 $\mu \mathrm{mol} \mathrm{m} \mathrm{m}^{-2} \mathrm{~s}^{-1}$ PPFD when $\Gamma$ was $465 \mathrm{ppm}$. 
Table IV. Calculated rates of net photosynthesis $\left(\mathrm{NP} \mu \mathrm{mol} \mathrm{CO} \mathrm{m}^{-2} \mathrm{~s}^{-1}\right)$ of B. subrotundifolium and B. pseudotriquetrum in response to $\mathrm{CO}_{2}$ concentration $\left(c_{\mathrm{a}}\right)$ as a function of moss turf temperature $\left(\mathrm{TT}^{\circ} \mathrm{C}\right)$ and incident PPFD $\left(\mu \mathrm{mol} \mathrm{m} \mathrm{m}^{-2} \mathrm{~s}^{-1}\right)$. Percentage increase of NP to $\mathrm{CO}_{2}$ increase using $360 \mathrm{ppm}$ as a reference level are given in parentheses.

\begin{tabular}{|c|c|c|c|c|}
\hline \multirow{2}{*}{$\begin{array}{l}\mathrm{TT} 0^{\circ} \mathrm{C} \\
c_{\mathrm{a}}(\mathrm{ppm}) \\
\end{array}$} & \multicolumn{4}{|c|}{$\operatorname{PPFD}\left(\mu \mathrm{mol} \mathrm{m} \mathrm{m}^{-2} \mathrm{~s}^{-1}\right)$} \\
\hline & 100 & 200 & 500 & 1350 \\
\hline \multicolumn{5}{|c|}{ Bryum subrotundifolium Cape Hallett 1999} \\
\hline 100 & $1.0(-50)$ & $1.4(-50)$ & $1.7(-55)$ & $2.1(-50)$ \\
\hline 200 & $1.8(-12)$ & $2.4(-12)$ & $3.4(-11)$ & $3.8(-11)$ \\
\hline 360 & 2.0 & 2.8 & 3.9 & 4.3 \\
\hline 800 & $3.0(50)$ & $4.1(48)$ & $5.4(40)$ & $6.8(57)$ \\
\hline 1000 & $2.2(10)$ & $3.2(14)$ & $4.2(8)$ & $5.5(28)$ \\
\hline 2000 & $2.0(0)$ & $2.8(0)$ & $3.8(-1)$ & $4.3(0)$ \\
\hline \multicolumn{5}{|l|}{$\mathrm{TT} 10^{\circ} \mathrm{C}$} \\
\hline 100 & $-0.8(-200)$ & $0.4(-90)$ & $1.5(-77)$ & $2.3(-79)$ \\
\hline 200 & $0.1(-92)$ & $1.9(-48)$ & $4.5(-30)$ & $6.6(-40)$ \\
\hline 360 & 0.8 & 3.7 & 6.4 & 11.1 \\
\hline 800 & $0.3(-61)$ & $4.0(8)$ & $8.8(38)$ & $13.8(23)$ \\
\hline 1000 & $0.9(8)$ & $4.4(20)$ & $9.6(50)$ & $14.6(31)$ \\
\hline 2000 & $1.4(72)$ & $4.9(35)$ & $10.3(63)$ & $15.6(40)$ \\
\hline \multicolumn{5}{|c|}{ Bryum pseudotriquetrum Cape Hallet 1999} \\
\hline \multicolumn{5}{|c|}{$\mathrm{TT} 0^{\circ} \mathrm{C}$} \\
\hline 100 & $0.6(-34)$ & $0.8(-52)$ & $1.0(-59)$ & $1.1(-66)$ \\
\hline 200 & $1.3(42)$ & $1.7(1)$ & $1.8(-22)$ & $2.3(-32)$ \\
\hline 360 & 0.9 & 1.7 & 2.4 & 3.3 \\
\hline 800 & $2.2(130)$ & $2.9(65)$ & $3.4(43)$ & $4.9(46)$ \\
\hline 1000 & 2.4 (157) & 3.4 (94) & $3.9(67)$ & $5.0(50)$ \\
\hline 2000 & $2.3(143)$ & $3.6(111)$ & $4.4(88)$ & $4.8(43)$ \\
\hline \multicolumn{5}{|l|}{$\mathrm{TT} 10^{\circ} \mathrm{C}$} \\
\hline 100 & $-1.2(-371)$ & $-0.9(-137)$ & $-0.4(-111)$ & $-0.2(-105)$ \\
\hline 200 & $0.4(-3)$ & $1.5(-41)$ & $2.3(-37)$ & $2.8(-38)$ \\
\hline 360 & 0.5 & 2.5 & 3.7 & 4.5 \\
\hline 800 & $1.3(181)$ & $3.9(58)$ & $7.0(90)$ & $8.6(92)$ \\
\hline 1000 & $0.8(71)$ & $3.5(41)$ & $6.6(78)$ & $8.3(87)$ \\
\hline 2000 & $0.9(98)$ & $4.8(95)$ & 7.8 (109) & $10.0(123)$ \\
\hline
\end{tabular}

\section{Discussion}

These studies were on three species of moss at two locations 5 degrees of latitude apart in the Ross Sea region and, although logistic limitations meant that only a small number of samples could be measured, it is an unusually large dataset for Antarctica. Opportunities, therefore, exist to try and separate variability in net photosynthesis inherent to species from that caused by location and external factors. High variability occurred within each species at each sampling as shown by large error bars in Fig. 5. When we can compare sites, then between year differences exceeded between site differences. The responses of NP to PPFD for B. subrotundifolium are more similar for Cape Hallett 1999, and Granite Harbour 2001, than between succeeding years at Granite Harbour (Fig. 5; Table III). Ceratodon purpureus at Granite Harbour showed large differences in consecutive years (Fig. 5) with $\mathrm{NP}_{\max }$ being almost double in the second season. As yet, we do not have sufficient information to identify the reasons for this variability. Length of period of snow cover and the occurrence of regular water flows are
Table V. $\mathrm{CO}_{2}$ compensation ( $\Gamma$, ppm) and carboxylation efficiency of Rubisco $(\alpha)$ of B. subrotundifolium and B. pseudotriquetrum (Cape Hallett 1999).

\begin{tabular}{|c|c|c|c|c|c|c|c|c|}
\hline \multirow{3}{*}{$\begin{array}{l}\text { PPFD } \\
\left(\mu \mathrm{mol} \mathrm{m}{ }^{-2} \mathrm{~s}^{-1}\right.\end{array}$} & \multicolumn{4}{|c|}{ B. subrotundifolium } & \multicolumn{4}{|c|}{ B. pseudotriquetrum } \\
\hline & \multicolumn{2}{|c|}{$\begin{array}{l}\text { 1) } \mathrm{CO}_{2} \\
\text { compensation } \\
\quad(\Gamma, \mathrm{ppm})\end{array}$} & \multicolumn{2}{|c|}{$\begin{array}{l}\text { Carboxylation } \\
\text { efficiency } \\
(\alpha)\end{array}$} & \multicolumn{2}{|c|}{$\begin{array}{c}\mathrm{CO}_{2} \\
\text { compensation } \\
(\Gamma, \mathrm{ppm})\end{array}$} & \multicolumn{2}{|c|}{$\begin{array}{c}\text { Carboxylation } \\
\text { efficiency } \\
(\alpha)\end{array}$} \\
\hline & $10^{\circ} \mathrm{C}$ & $20^{\circ} \mathrm{C}$ & $10^{\circ} \mathrm{C}$ & $20^{\circ}$ & $10^{\circ} \mathrm{C}$ & $20^{\circ} \mathrm{C}$ & $10^{\circ} \mathrm{C}$ & $20^{\circ} \mathrm{C}$ \\
\hline ? 50 & - & - & 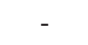 & - & $\begin{array}{ll}- \\
-\end{array}$ & 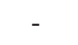 & - & - \\
\hline & 181 & - & & 0.0 & 17 & 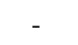 & & 0 . \\
\hline 200 & $<100$ & 284 & 0.022 & 0.029 & 125 & 465 & 0.019 & 0.018 \\
\hline 500 & $<100$ & 147 & 0.028 & 0.039 & 111 & 176 & 0.022 & 0.032 \\
\hline 1000 & $<100$ & 128 & & & 103 & 185 & & \\
\hline $\max$ & $<100$ & 120 & 0.047 & 0.047 & $<100$ & 181 & 0.024 & 0.035 \\
\hline
\end{tabular}

likely to be important but this variability adds complexity to attempts to detect the effects of long-term climate change.

Water availability is probably the most decisive ecological variable for the nature and distribution of moss communities in continental Antarctica (Kennedy 1993). Bryophytes depend on liquid water uptake for metabolic activity (Kappen \& Valladares 1999), and water availability is linked to temperature, incident radiation and a local supply of meltwater. The major water sources are melting recent snow fall, and meltwater from semi-permanent snow patches and permanent ice. Precipitation occurs mainly in autumn and winter and is light and infrequent in summer (Kappen \& Schroeter 1997). Meltwater streams may occur for about two months in the summer season effectively prolonging the active phase of the plants (Howard-Williams \& Vincent 1986, Smith 1999). It has been suggested that their physiological performance would then be mainly dependent on their microclimate (Schlensog \& Schroeter 2000, Kappen \& Schroeter 2002, Pannewitz et al. 2003a, 2003b).

The mosses themselves appeared to be well adapted to high water availability and have relatively broad ranges of WC over which NP was near maximal (390-470\% d.wt for B. subrotundifolium and $245-330 \%$ d.wt. for B. pseudotriquteum). Smith (1999) measured sustained high NP for these species at very high WC that were found to cause depression in NP here (B. argenteum: 790\%, B. pseudotriquetrum: $670 \%$ and C. purpureus: $470 \%$ d.wt.). However, the measurements (Smith 1999) were made at very high $\mathrm{CO}_{2}$ levels (about 5\%) and these would have minimized any depression in NP due to higher $\mathrm{CO}_{2}$ diffusion resistances at high WC. Differences in the optimal WC for NP may be related to the water availability at the sample sites, as summarized by Kappen \& Schroeter (2002): xeric species had optimal NP at $200-300 \%$ d.wt. compared to over $500 \%$ d.wt in hydric species.

The November/December 2000 and January 2001 season at Granite Harbour appeared to be aberrant because meltwater streams from the local glacier did not occur before 16 January (personal observation) and B. subrotundifolium was inactive for a long period after the 
snowmelt. We suspect that this was because of cooler than normal air temperatures and emphasises, once again, the importance of macroclimate and year-to-year climate variability. Cryptogamic communities are suggested to be highly sensitive to long term global change where the balance between freezing and melting is precarious (Vincent 1997).

Climate change in Antarctica is under debate due to the differences between observed local changes and modelpredicted global temperature trends. There has been a warming over the Antarctic Peninsula but a cooling between 0.08 and $0.7^{\circ} \mathrm{C}$ per decade during the last 30 years over East Antarctica (Comiso 2000, Doran et al. 2002, Thompson \& Salomon 2002, Shindell \& Schmidt 2004). Bertler et al. (2004) recognized that the Antarctic cooling appears to be restricted to the last two decades and that averaged over the past 40 years there has been a slight warming. Recent simulations, which include recovery of the ozone layer suggest that changes in the Southern Hemisphere climate may reverse the cooling trend (Shindell \& Schmidt 2004) and that warming will dominate in future in continental Antarctica. However, an expected temperature increase of $0.9-1.2^{\circ} \mathrm{C}$ per century (IPCC 2001) might well have little direct effect on the melting process, because temperatures, in general, are well below zero, even during summer. Other, at present unpredictable changes, such as in the occurrence of cloud and precipitation, are likely to have important, both positive and negative, effects on vegetation in continental Antarctica.

The second, important factor that influenced NP was thallus temperature. Comparison of the two Bryum species at Cape Hallett, showed very depressed NP at all combinations of PPFD and $\mathrm{CO}_{2}$ concentration at $0^{\circ} \mathrm{C}(75 \%$ depressed) and $10^{\circ} \mathrm{C}(33-50 \%$ depressed) compared to rates at $20^{\circ} \mathrm{C}$. Although thallus temperatures could be warm at times of high insolation, up to around $20^{\circ} \mathrm{C}$ for hydrated mosses, temperatures around $0^{\circ} \mathrm{C}$ were more common so that, for B. subrotundifolium at Granite Harbour, plants were between -2 and $+2^{\circ} \mathrm{C}$ for $58 \%$ of readings. Optimal temperatures for NP certainly fell within the range of temperatures met by the plants but were well above the more common TT. Ceratodon purpureus had a much lower optimal temperature for $\mathrm{NP}\left(6.6^{\circ} \mathrm{C}\right)$ than $B$. pseudotriquetrum $\left(12.0^{\circ} \mathrm{C}\right)$ and $B$. subrotundifolium $\left(13.7^{\circ} \mathrm{C}\right)$. At present we have no explanations for between-species differences in optimal temperatures for NP and the ecological relevance is far from obvious when one considers that B. subrotundifolium, for example, operated at maximal NP under optimal conditions for only $0.1 \%$ of the potentially active time period (23 November 2000 and 24 January 2001). The optimal values fall within the temperature range reported for maximal growth rate for B. argenteum $\left(15-22^{\circ} \mathrm{C}\right.$; Longton \& MacIver 1977, Smith 1999) but substantially lower than the $25-30^{\circ} \mathrm{C}$ reported by Rastorfer (1970).
Photosynthetic activity of all three species was low but, still detectable at $-5^{\circ} \mathrm{C}$ TT and TT below $-5^{\circ} \mathrm{C}$ were found to be tolerated, even in the hydrated state. This contrasts with the suggestion that $\mathrm{CO}_{2}$ gas exchange ceases as soon as the water freezes in mosses (Kappen \& Schroeter 2002) but agrees with Ino (1990) who detected photosynthetic activity to $-10^{\circ} \mathrm{C}$ TT. This tolerance is certainly necessary because the mosses can undergo freeze/thaw cycles almost every day during the summer season (Rudolph 1966a), with the lowest thallus temperatures being around $-10^{\circ} \mathrm{C}$. However, the mosses do not reach these low temperatures when highly hydrated because of the buffering effect due to latent heat released during the freezing of water (Fig. 1; Pannewitz et al. 2003a).

All three species had photosynthetic features that might be expected from high-light or sun adapted specimens. Photosynthetic compensation $\left(\mathrm{L}_{\mathrm{c}}\right)$ at near optimal TT was between $70 \mu \mathrm{mol} \mathrm{m} \mathrm{m}^{-2} \mathrm{~s}^{-1}$ and $95 \mu \mathrm{mol} \mathrm{m} \mathrm{m}^{-2} \mathrm{~s}^{-1}$ for C. purpureus and $130 \mu \mathrm{mol} \mathrm{m} \mathrm{m}^{-2} \mathrm{~s}^{-1}$ for B. pseudotriquetrum. However, $\mathrm{L}_{\mathrm{c}}$ was temperature dependent and, at $15^{\circ} \mathrm{C}$ TT, were high, between $135 \mu \mathrm{mol} \mathrm{m} \mathrm{s}^{-2} \mathrm{~s}^{-1}$ and $235 \mu \mathrm{mol} \mathrm{m}^{-2} \mathrm{~s}^{-1}$, for B. subrotundifolium, around $260 \mu \mathrm{mol} \mathrm{m} \mathrm{m}^{-2} \mathrm{~s}^{-1}$ for B. pseudotriquetrum and $370 \mu \mathrm{mol} \quad \mathrm{m}^{-2} \mathrm{~s}^{-1}$ for C. purpureus. These are expected values for mosses growing in the full Antarctic sun light (Green et al. 2000b).

NP was not saturated at the highest tested PPFD and did not decline at optimal TT due to high PPFD although this has been found in other Antarctic species (Kappen et al. 1989, Lovelock et al. 1995a, 1995b). Recent research on Antarctic mosses from sun exposed sites with sufficient water supply suggest that NP is not saturated at high insolation (Green et al. 2000b) and photoinhibition must not necessarily be expected (Schlensog \& Schroeter 2000, Green et al. 2000b, Schlensog 2001, Lud et al. 2002, Pannewitz et al. 2003a). This is probably not surprising, because the mosses often encounter high light levels at times of greatest water availability and one would expect substantial protection. Bryum pseudotriquetrum contains considerable quantities of UV-B absorbing compounds (Dunn 2000) and Bryum species generally show the ability to accumulate flavonoids, highly effective preventors of damage from UV radiation (Robinson et al. 2003, Cockell \& Knowland 1999). Post (1990) found photoprotective substances in $C$. purpureus that, perhaps, reduce the light intensities at the chloroplast level. This is supported by the results of Smith (1999) who found that samples of C. purpureus lost their pigmentation when kept beneath UV-B filters. Smith (1999) reported a significant growth increase in $B$. argenteum in the absence of UV-B suggesting a metabolic cost for the protection. The photosynthetic apparatus of bryophytes has been described as shadeadapted; a property normally associated with low light compensation points and low light saturation levels (Valanne 1984, Green et al. 1999, Kappen \& Schroeter 2002). The results presented here with the high light 
compensation and lack of light saturation of NP would tend to suggest that the plants were sun plants. This is in agreement with Marschall \& Proctor (2004) who recently concluded that bryophytes include but are not inherently shade plants. However, it must be remembered that if there is substantial protection against high PPFD in the form of pigments or refractive structures then little light might reach the photosynthetic centres. The species could, perhaps, be better considered as being protected shade plants.

The two Bryum species differed substantially in their response to $\mathrm{CO}_{2}$. Bryum pseudotriquetrum showed no saturation up to $2000 \mathrm{ppm} \mathrm{CO}_{2}$, particularly at $20^{\circ} \mathrm{C}$, whilst B. subrotundifolium was saturated at $\mathrm{CO}_{2}$ concentrations above about $1000 \mathrm{ppm}$. The NP of both species, therefore, were substantially limited at normal ambient $\mathrm{CO}_{2}$ levels of $360 \mathrm{ppm}$. When measured at an increased $\mathrm{CO}_{2}$ level of 2000 ppm, net photosynthetic rates for $B$. subrotundifolium were $60-80 \%$ higher than at the accepted ambient level of 360 ppm and NP of B. pseudotriquetrum was more than doubled. These were only short-term experiments and such an enhancement might be short-lived under natural conditions, as demonstrated for the moss Hylocomium splendens (Sonesson et al. 1996) and Arctic higher plants (Oechel et al. 1997). Sustained, increased photosynthesis over extended time periods requires sufficient nutrient availability or improved nutrient use efficiency (Oechel \& Billings 1992). Nutrient deficiency seems to be unlikely at sites like Cape Hallett which are rich in bird life (Green et al. 2000a, 2000b) and has been very rarely shown in Antarctic bryophytes (Kappen \& Schroeter 2002). A $0.2-0.8 \%$ increase of the amount of $\mathrm{CO}_{2}$ in the atmosphere per year, as being used in global change models (IPCC 2001), would have few consequences on the carbon metabolism of $B$. subrotundifolium and $B$. pseudotriquetrum in the short term. The photosynthetic rates of both Bryum species were certainly increased by experimentally generated elevated $\mathrm{CO}_{2}$ but, because ambient levels might already be high (Tarnawski et al. 1992, Green et al. 2000a) the effect of increasing background atmospheric $\mathrm{CO}_{2}$ concentrations could be minimal.

\section{Summary}

The high variability in NP response to major factors like PPFD and the present lack of any understanding of the causes means that it will be difficult to use the results of carbon dioxide exchange studies to detect or predict the effects of climate change, especially warming. We also need to learn more about the carbon balance of these mosses to discover if they are in a carbon shortage or whether utilisation of photosynthetic products is the real limitation as suggested for alpine plants (Körner 2003). It is, perhaps, too early to predict what the effects of global climate change will be in these polar environments.

\section{Acknowledgements}

S.P., M.S. and B.S. gratefully acknowledge financial support by Deutsche Forschungs Gemeinschaft (DFG SCHR 473/4-3). LGS thanks the Spanish Ministry of Science (REN2003-07366-C01). TGAG and KM thank Professor Bryan Gould, Vice-Chancellor of Waikato University for continued funding of the Antarctic research programme. Antarctica New Zealand is thanked for providing logistics. A special thanks to the Australian Antarctic Programme for their extensive logistic support at Cape Hallett, and to the United States Coastguard, Captain and crew of USCGC Polar Sea (WAGB 11) for their professional support during the transport to and from Cape Hallett. We thank Dr Peter Convey and an unnamed referee for their comments on an earlier draft.

\section{References}

Bertler, N.A.N., Barrett, P.J., Mayewski, P.A., Fogt, R.L., Kreutz, K.J. \& Schulmeister, J. 2004. El Niño suppresses Antarctic warming. Geophysical Research Letters, 31, doi: 10.1029/2004GL020749.

Canadell, J.G., Mooney, H.A., Baldocchi, D.D., Berry, J.A., Ehleringer, J.R., Field, C.B., Gower, S.T., Hollinger, D.Y., Hunt, J.E., Jackson, R.B., Running, S.W., Shaver, G.R., Steffen, W., Trumbore, S.E., VAlentini, R. \& Bond, B.Y. 2000. Carbon metabolism of the terrestrial biosphere: a multitechnique approach for improved understanding. Ecosystems, 3, 115-130.

Cockell, C.S. \& Knowland, J. 1999. Ultraviolet radiation screening compounds. Biological Review, 74, 311-345.

Comiso, J.C. 2000. Variability and trends in Antarctic surface temperatures from in situ and satellite infrared measurements. Journal of Climate, 13, 1674-1696.

Doran, P.T., Priscu, J.C., Lyons, W.B., Walsh, J.E., Fountain, A.G., McKnight, D.M., Moorhead, D.L., Virginia, R.A., Wall, D.H., Clow, G.D., Fritsen, C.H., McKay, C.P. \& Parsons, A.N. 2002. Antarctic climate cooling and terrestrial ecosystem response. Nature, 415, 517-519.

DunN, J.L. 2000. Seasonal variations in the pigment content of three species of Antarctic bryophytes. BSc thesis, University of Wollongong, Australia. [Unpublished]

Green, T.G.A., Schroeter, B. \& Sancho, L. 1999. Plant life in Antarctica. In Pugnaire, F.I. \& Valladares, F., eds. Handbook of functional plant ecology, vol. 14. New York: Marcel Dekker, 496-543.

Green, T.G.A., Maseyk, K., Pannewitz, S. \& Schroeter, B. 2000a. Extreme elevated in situ carbon dioxide levels around the moss Bryum subrotundifolium Jaeg., Ber. S. Gall. in Antarctica. Bibliotheca Lichenologica, 75, 397-403.

Green, T.G.A., Schroeter, B. \& Seppelt, R.D. 2000b. Effect of temperature, light and ambient UV on the photosynthesis of the moss Bryum argenteum Hedw. in continental Antarctica. In DAvidson, W., Howard-Williams, C. \& Broady, P., eds. Antarctic ecosystems: models of wider ecological understanding. Christchurch, New Zealand: Caxton Press, 165-170.

Green, T.G.A., Kulle, D., Pannewitz, S., Sancho, L.G. \& Schroeter, B. in press. UV-A protection in mosses growing in continental Antarctica. Polar Biology.

Howard-Williams, C. \& Vincent, W. 1986. Ecosystem properties of Antarctic streams. New Zealand Antarctic Record, 6, 21-27.

INO, Y. 1990. Field measurements of net photosynthesis of mosses at Langhovde, East Antarctica. Ecological Research, 5, 195-205. 
IPCC. 2001. Polar Regions (Arctic and Antarctic). In MCCARTHY, J.J., CanZiani, O.F., Leary, N.A., DokKen, D.J. \& White, K.S., eds. Third Assessment Report. Climate Change 2001: Impacts, Adaptation, and Vulnerability, vol. 16. ICPP 2001. Cambridge, UK: Cambridge University Press, 801-842.

Kappen, L., SMith, R.I.L. \& Meyer, M. 1989. Carbon dioxide exchange of two ecodemes of Schistidium antarctici in continental Antarctica. Polar Biology, 9, 415-422.

Kappen, L. \& Schroeter, B. 1997. Activity of lichens under the influence of snow and ice. Proceedings NIPR Symposium on Polar Biology, 10, $163-168$.

Kappen, L. \& Valladares, F. 1999. Opportunistic growth and desiccation tolerance: the ecological success of poikilohydrous autotrophs. In Pugnaire, F.I. \& Valladares, F., eds. Handbook of functional ecology. New York: Marcel Dekker, 9-80.

Kappen, L. \& Schroeter, B. 2002. Plants and lichens in the Antarctic, their way of life and their relevance to soil formation. In BEYER, L. \& BöLTER, M., eds. Geoecology of Antarctic ice-free coastal landscapes. Berlin: Springer, 327-373.

KENNEDY, A.D. 1993. Water as a limiting factor in the Antarctic terrestrial environment: a biogeographical synthesis. Arctic \& Alpine Research, 25, 308-315.

KÖRNER, C. 2003. Carbon limitation in trees. Journal of Ecology, 91, 4-17.

Lewis Smith, R.I., Walton, D.W.H. \& Dingwall, P.R. 1994. Developing the Antarctic Protected Area System. Cambridge: IUCN, 138 pp.

Longton, R.E. \& MacIver, M.A. 1977. Climatic relationship in the Antarctic and Northern Hemisphere populations of the cosmopolitan moss Bryum argenteum Hedw. In Llano, G.A., ed. Adaptation within Antarctic ecosystems. Proceedings of the third SCAR Symposium on Antarctic Biology. Washington, DC: Smithonian Institution, 899-919.

Longton, R.E. 1988. The biology of polar bryophytes and lichens. Cambridge: Cambridge University Press, $391 \mathrm{pp}$.

Lovelock, C.E., Jackson, A.E., Melick, D.R. \& Seppelt, R. 1995a. Reversible photoinhibition in Antarctic moss during freezing and thawing. Plant Physiology, 109, 955-961.

Lovelock, C.E., Osmond, C.B. \& Seppelt, R.D. 1995b. Photoinhibition in the Antarctic moss Grimmia antarctici Card. when exposed to cycles of freezing and thawing. Plant, Cell and Environment, 18, 1395-1402.

Lud, D., MoerdiJK, T.C.W., van de Poll, W.H., Buma, A.G.J. \& Huiskes, A.H.L. 2002. DNA damage and photosynthesis in Antarctic and Arctic Sanionia uncinata (Hedw.) Loeske under ambient and enhanced levels of UV-B radiation. Plant Cell and Environment, 25, 1579-1589.

Marschall, M. \& Proctor, M.C.F. 2004. Are bryophytes shade plants? Photosynthetic light response and proportions of chlorophyll $a$, chlorophyll $b$ and total carotenoids. Annals of Botany, 94, 593-603.

NewSHAM, K.K. 2003. UV-B radiation arising from stratospheric ozone depletion influences the pigmentation of the Antarctic moss Andrea regularis. Oecologia, 135, 327-331.

OchYRA, R. 1998. The moss flora of King George Island Antarctica. Cracow: Polish Academy of Science, W. Szafer Institute of Botany, 278 pp.

Oechel, W.C. \& Billings, W.D. 1992. Anticipated effects of global change on carbon balance of arctic plants and ecosystems. In CHAPIN, F.S.I., Jefferies, R.L., Reynolds, J., Shaver, G. \& Svoboda, J., eds. Arctic ecosystems in a changing climate: an ecophysiological perspective. San Diego, CA: Academic Press, 139-169.

Oechel, W.C., Cook, A.C., Hastings, S.J. \& Vourlitis, G.L. 1997. Effects of $\mathrm{CO}_{2}$ and climate change on arctic ecosystems. In Woodin, S.J. \& MARQUIS, M., eds. Ecology of Arctic environments. Cambridge: Cambridge University Press, 255-273.

Pannewitz, S., Green, T.G.A., Scheidegger, C., Schlensog, M. \& Schroeter, B. 2003a. Activity pattern of the moss Hennediella heimii (Hedw.) Zand. in the Dry Valleys, Southern Victoria Land, Antarctica during the mid austral summer. Polar Biology, 26, 545-551.

Pannewitz, S., Schlensog, M., Green, T.G.A., Sancho, L.G. \& Schroeter, B. 2003b. Are lichens active under snow in continental Antarctica? Oecologia, 135, 30-38.
Pontaillier, J.-Y. 1990. A cheap quantum sensor using gallium arsenide photodiode. Functional Ecology, 4, 591-596.

Post, A. 1990. Photoprotective pigment as an adaptive strategy in the Antarctic moss Ceratodon purpureus. Polar Biology, 10, 241-245.

RASTORFER, J.R. 1970. Effects of light intensity and temperature on photosynthesis and respiration of two East Antarctic mosses, Bryum argenteum and Bryum antarcticum. Bryologist, 73, 544-556.

Robinson, S.A., WASLEy, J. \& ToBin, A.K. 2003. Living on the edge plants and global change in continental and maritime Antarctica. Global Change Biology, 9, 1681-1717.

RUDOLPH, E.D. 1966a. Terrestrial vegetation of Antarctica: past and present studies. Antarctic Research Series, 8, 109-122.

RudolPh, E.D. 1966b. Lichen ecology and microclimate studies at Cape Hallet, Antarctica. Proceedings of the Third International Biometeorological Congress. Oxford: Pergamon Press, 900-910.

Schlensog, M. \& Schroeter, B. 2000. Poikilohydry in Antarctic cryptogams and its role for photosynthetic performance in mesic and xeric habitats. In Davidson, W., Howard-Williams, C. \& Broady, P., eds. Antarctic ecosystems: models for wider ecological understanding. Christchurch, New Zealand: The Caxton Press, 175-182.

SChlensog, M. 2001. Zur Photosynthese antarktischer Kryptogamen unter besonderer Berücksichtigung von Photoinhibition. Berlin: Mensch und Buch Verlag, $113 \mathrm{pp}$.

Schlensog, M., Pannewitz, S., Green, T.G.A. \& Schroeter, B. 2004. Metabolic recovery of Continental Antarctic cryptogams after winter. Polar Biology, 27, 399-408.

Schroeter, B., Green, T.G.A., Kappen, L. \& Seppelt, R.D. 1994. Carbon dioxide exchange at subzero temperatures. Field measurements on Umbilicaria aprina in Antarctica. Cryptogamic Botany, 4, 233-241.

SEPPELT, R.D. 1984. The bryoflora of the Vestfold Hills and the Christensen Coast, Antarctica. ANARE Research Notes, 20, 1-31.

Seppelt, R.D., Green, T.G.A. \& Schroeter, B. 1995. Lichens and mosses from the Kar Plateau, southern Victoria Land, Antarctica. New Zealand Journal of Botany, 34, 203-220.

Seppelt, R.D. \& Green, T.G.A. 1998. A bryophyte flora for southern Victoria Land, Antarctica. New Zealand Journal of Botany, 36, 615-632.

Shindell, D.T. \& Schmidt, G.A. 2004. Southern Hemisphere climate response to ozone changes and greenhouse gas increases. Geophysical Research Letter, 31, doi:10.1029/2004GL020724.

SMITH, R.I.L. 1984. Terrestrial plant biology of the sub-Antarctic and Antarctic. In Laws, R.M., ed. Antarctic ecology, vol. 1. London: Academic Press, 61-162.

SмITH, R.I.L. 1999. Biological and environmental characteristics of three cosmopolitan mosses dominant in continental Antarctica. Journal of Vegetation Research, 10, 231-242.

Sonesson, M., Callaghan, T.V. \& Carlsson, B.A. 1996. Effects of enhanced ultraviolet radiation and carbon dioxide concentration on the moss Hylocomnium splendens. Global Change Biology, 2, 67-73.

Tarnawski, M., Melick, D., Roser, D., Adamson, E., Adamson, H. \& SEPPELT, R. 1992. In situ carbon dioxide levels in cushion and turf forms of Grimmia antarctici at Casey Station, east Antarctica. Journal of Bryology, 17, 241-249.

TAYLOR, G. 1913. The western journeys. In HuXLEy, L., eds. Scott's last expedition. London: Smith Elder, 182-291.

Thompson, D.W.J. \& Solomon, S. 2002. Interpretation of recent southern hemisphere climate change. Science, 296, 895-899.

Valanne, N. 1984. Photosynthesis and photosynthetic products in mosses. In Dyer, A.F. \& DucketT, J.G., eds. The experimental biology of bryophytes. London: Academic Press, 257-273.

VINCENT, W.F. 1997. Polar desert ecosystems in a changing climate: A north-south perspective. In Lyons, W.B., Howard-Williams, C. \& HAWES, I., eds. Ecosystem processes in Antarctic ice-free landscapes. Rotterdam: Balkema, 275-279. 